\title{
Landscape Diversity: Multiple-Use Landscapes for Reclaimed Phosphatic Clay Areas ${ }^{1}$
}

E.A. Hanlon ${ }^{2}$

\section{Intent}

Explore the benefits of using reclaimed phosphatic clay areas, a result of phosphate mining in central Florida, for multiple purposes to add to the local economy and the sustainability of the community and to take advantage of the clay resource for environmental and agricultural purposes. This document is written as a concept paper, which integrates information learned about phosphatic clay (for example, Phosphatic Clay for Agricultural Uses: Bibliography, http://edis.ifas.ufl.edu/SS444, URL checked August 9, 2005).

\section{Description of phosphatic clay areas}

1. Phosphatic clay is one of the by-products of phosphate mining.

a) The phosphatic clay material is mostly in the clay-size fraction, usually containing both Montmorillonite and Palygorskite with some phosphorites. 
a) The depth of phosphatic clay will vary with the underlying terrain (Fig. 2). Where a valley exists in the floor of the phosphatic clay containment area, the phosphatic clay deposit will be the deepest.

4. As the phosphatic clay dewaters during the reclamation process (active use for mining purposes has ceased), the phosphatic clay undergoes subsidence or more appropriately differential settling.

a) Where clay deposits are the deepest, the most differential settling will occur.

i) The effects of differential settling on the phosphatic clay surface can be observed in as few as 4 or 5 years after reclamation.

ii) Differential settling will continue until the bulk density of the phosphatic clay increases sufficiently to support the weight of the phosphatic clay above. Typically, reclaimed phosphatic clay has a bulk density from 0.6 to $1.2 \mathrm{~g} \mathrm{~cm}^{-3}$. This wide range is a reflection of both the variability of its composition and the stage of differential settling.

(a) In a 3-year trial on an unmined phosphatic clay area involving selected rates of biosolids, the phosphatic clay bulk density remained at $0.9 \mathrm{~g} \mathrm{~cm}^{-3}$. However, the depth of the phosphatic clay was only 1 meter.

(b) At several other phosphatic clay sites where macrobeds, drainage landforms for intensive use of phosphatic clay developed by the author, were built in the mid-1990s, differential settling has destroyed the macrobeds. Clay depths varied from 1 meter to more than 20 meters.

(i)The added weight of phosphatic clay along the small ridge of the macrobed may actually exacerbate differential settling.

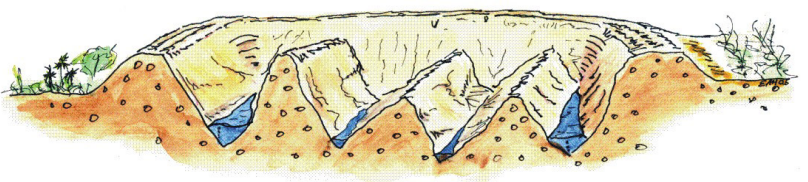

Figure 1. This concept drawing shows the landscape that will be used for the deposition of phosphatic clay, the so-called containment area. Note the windrows of materials and the formation of a berm around the perimeter. The shape of this basin will affect the shape of the phosphatic clay after reclamation and differential settling.

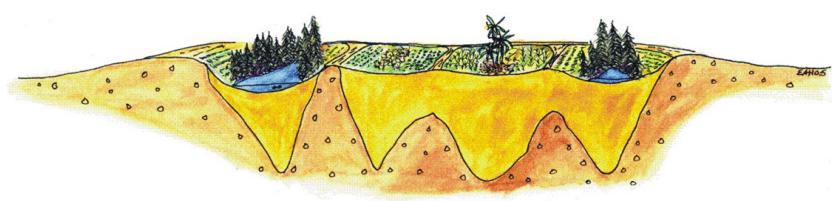

Figure 2. The same site is shown after clay deposition, reclamation, and several years into the differential settling process. Note that the berm has been reshaped and managers have used the multiple-use landscape approach immediately after reclamation of the surface. Tree planting and location of access roads are based upon underlying strata. Deeper zones of phosphatic clay have been set aside for water and wetlands. Filter strips surround these low areas. An assortment of crops (sod, energy crops, forages, native grasses for seed/transplanting) is positioned in the landscape based upon slope and drainage considerations. In this concept drawing, differential settling and original underlying strata have occurred at different rates. Note that the underlying strata is used as a road (left side of drawing and to the immediate right of trees) since this material extends to the surface. The phosphatic clay to the right of that road contains row crops and a swale in the middle for drainage and water quality considerations. Steeper land (far right on the side of the residual berm) is in grasses for stability on the slope.

\section{Considerations for land forming the settling basin (containment area) or shaping the phosphatic clay surface in the future}

1. As stated above, the landscape (elevations) of the final phosphatic clay surface is related to the underlying landforms of the containment area comprising the bottom of the clay settling pond. 
a) Prediction of the final phosphatic clay surface that is well into the differential settling phase is possible if the original landform is known or can be estimated.

b) A corollary to this statement is that the landscape of a newly designed settling pond can greatly control the final phosphatic clay landscape.

i) Costs for reclamation and resulting phosphatic clay landform vs. costs for land forming before initial phosphatic clay introduction must be compared along with the potential increased value of the land area after reclamation.

(a) Studies that explore initial reclamation, formation of macrobeds, and discharge water treatment facilities have been completed.

(ii) Given the long, useful life of a settling pond during active mining operations and the problems facing reclamation efforts afterward, the decision-making process must be conducted with care.

\section{A strategy for fully utilizing phosphatic clay areas}

1. Develop a prediction of the phosphatic clay landscape as it is likely to be well into the differential settling phase.

a) Use this prediction to create landscape diversity or a so-called multiple-use landscape.

b) Where clay deposits are deepest, plan isolated or connected wetlands; some will likely have a free water surface.

c) Where clay deposits are of intermediate depth and adjacent to deeper deposits, use this sector for filtration zones with plant selection based upon expected wetness or hydroperiod (if close to a free water source). i) The capillary water movement through phosphatic clay is considerable, both laterally and vertically; however, the movement is slow due to reduced hydraulic conductivity.

ii) When dried, cracks as wide as $10 \mathrm{~cm}$ (4 inches) will form at the surface, extending downward more than $30 \mathrm{~cm}(1$ foot) due to the shrink/swell properties of the montmorillonite clay.

(a)This cracking will cause:

(i) Vertical mixing, often moving organic matter deeper into the phosphatic clay profile;

(ii) Ready entrapment of rainfall, often capturing as much as $2.5 \mathrm{~cm}$ (1 inch) without appreciable runoff;

(iii) Possible root damage for some plants.

d) Where phosphatic clay depths are relatively shallow, cropping systems and vehicle access should be established.

i) Trafficability of phosphatic clay is problematic during the wet season, and special consideration should be given to movement of equipment.

(a) Perennial peanut (rhizome-type) has shown to be effective when planted as a sod for traffic rows in a wide range of phosphatic clay moisture conditions.

(b) Use of specially developed equipment for use on phosphatic clay has been explored, but advances in articulation and robotic arms are still to be investigated.

\section{Advantages and disadvantages}

1. A plan, available at the beginning of the reclamation phase and anticipating the final land forms after differential settling (years into the 
future), will eliminate costly intermediate development, such as the construction of inappropriately placed macrobeds that cross both deep and shallow clay deposits.

2. Plantings, such as cypress in what will become the lower surfaces after differential settling, can actually facilitate the dewatering process.

a) Use of municipal composts as a mulch for the cypress planting and associated tree species will:

i) Offer a disposal area for the municipality at no or low cost;

ii) Recycle nutrients and organic matter in a sustainable way;

iii) Repress other plant competitors (e.g., black willow), allowing cypress to form a canopy more quickly.

b) Municipal waste-stream separation techniques have improved greatly, and hazards of trace metals are extremely low.

c) Some phosphatic clay land could be used to compost municipal organics on a commercial scale.

i) Several large vegetable and citrus corporations in southwest Florida already do commercial composting, which benefits plants growing in these sandy soils and assists municipalities in a sustainable manner.

ii) Additions of organic matter to the phosphatic clay will help with tillage, water control, and nutrient recycling.

3. The design of the multiple-use landscape means:

a) Not all phosphatic clay land will be in commercial production;

b) Plantings of row crops may be on or slightly across the contour; and c) Short rows mean requirements for smaller and/or specialized equipment.

4. The multiple-use-landscape concept offers the promise of a water efficient system.

a) Because of the slow hydraulic conductivity, phosphatic clay areas will contribute to groundwater recharge, especially if the lower elevations in the landscape are devoted to a wetlands scenario.

b) Water harvesting within the phosphatic clay area is possible, reusing any runoff from the agricultural zone and after that water has passed through the filtration zone, described above.

i) Due to the high water holding capacity of the phosphatic clay and with water recycling, the area is likely to pose little burden on other surficial or aquifer sources.

5. Use of the final land form (the shape of the containment area into which the phosphatic clay has been placed, see Figures 1 and 2) as a decision tool regarding early plantings and construction means less reclamation expense and loss.

a) Macrobeds can be properly located to avoid future differential settling problems.

b) Traffic patterns based upon ridges/shallow clay zones will decrease vehicular problems (getting stuck, destroying a prepared planting surface, etc.). 